\title{
SPECIES DIVERSITY AND LONGEVITY OF ORDOVICIAN GRAPTOLITES - INFLUENCE OF HABITAT
}

COOPER, Roger A., Institute of Geological and Nuclear Sciences, PO Box 30368, Lower Hutt, New Zealand.

The Ordovician graptolite sequence of Austalasia is one of the richest and most finely zoned in the world. Thirty-two zones and subzones are recognised. The recent census and review of the zonal distribution of Australasian graptolites therefore provides a high resolution data set for analysis of diversity change and origination and extinction rate, at the species level, in a planktic animal group. An improved relative timescale for the Ordovician has been devised using, primarily, the depositional rates of deep sea shales. calibrated by SHRIMP zircon dates; it is used to measure the macroevolutionary rates of the Australasian graptolite sequence.

The origination, extinction and diversity curves are very uneven but show closely similar patterns. The standing diversity curve shows two intervals of high diversity sharply demarked from a background of low diversity. For the first $25 \%$ of Ordovician time graptolites remained at low diversity but a spectacular radiation in the dichograptids at the base of the Arenig produced the greatest diversity ( 70 species and subspecies) reached during Ordovician time. During the remaining Arenig and Llanvirn (= late Ibexian to late Whiterockian) origination and extinction rates remained generally high but fluctuated strongly. Diversity also remained at a high but fluctuating level. A long period of relatively low diversity followed, and then, in the late Caradoc and Ashgill (= Cincinnatian), another peak in diversity is reached ( 50 species and subspecies), about 4 my before the end of the Ordovician. The decline in diversity from this peak to the end of the Ordovician was dramatic and brought about the near total extinction of the group (only 3 species survived in the Australasian sequence). It was brought about by a rapid decline in originations combined with two sharp spikes in the extinction rate.

Causes of the changes in diversity are uncertain. The basal Arenig radiation and following interval of high (fluctuating) diversity was accompanied by a major sea level rise and period of high stand, but comparable earlier (Tremadoc) and later (Caradoc) flooding events were not accompanied by increased diversity in graptolites. The late Caradoc peak may correspond to that shown by several marine groups (reviewed by Sepkoski) but graptolites do not show the preceding progressive build up, through the Llandeilo-Caradoc, shown by most other groups. The terminal Ordovician extinction event is undoubtedly part of the global mass extinction attributed to causes associated with glaciation and climate deterioration.

Average species longevity is $3.9 \mathrm{my}$ and ranges from $8.3 \mathrm{my}$ for dicranograptids to $1.5 \mathrm{my}$ for sigmagraptids. This compares with $1 \mathrm{my}$ for ammonites and $20-27 \mathrm{my}$ for planktic forams. Average species longevity in the largest group, the dichograptids (with 91 species and subspecies), is $2.6 \mathrm{my}$. Thirty-one percent of all species and subspecies have a duration of less than $1 \mathrm{my}$. The relatively short average time span of graptolite species combined with their wide distribution render them valuable fossils for correlation.

Interestingly, the average duration of species of the deep water $(+150 \mathrm{~m}$ depth) graptolite biotope, $2.2 \mathrm{my}$, is less than half that of species of the shallow water (epipelagic) biotope at $5.3 \mathrm{my}$. Possible reasons for this will be discussed. 